\title{
A FILIAÇÃO SOCIOAFETIVA E A AÇÃO DE PETIÇÃO DE HERANÇA
}

\author{
Cassiane Araujo Boeira \\ Ida Beatriz De Luca
}

\section{INTRODUÇÃO}

Por disposição expressa da Constituição da República Federativa do Brasil, é garantido o direito à herança. Tal garantia, elencada no art. $5^{\circ}$, inciso XXX, é considerada, como todas as outras garantias individuais e coletivas relacionadas no artigo, algo de primordial importância ao cidadão e à sociedade.

A inclusão do direito de herança em um dos incisos do art. $5^{\circ}$ dá a ela o status de direito fundamental, sendo expressamente vedada qualquer proposta de emenda tendente a abolila (art. 60, §4 ${ }^{\circ}, \mathrm{CF}$ ).

Entretanto, em que pese a importância dada ao direito de herança por nosso ordenamento jurídico, não são raros os casos em que o filho herdeiro se vê preterido, impedido de alcançá-la.

É o caso, por exemplo, do filho socioafetivo não reconhecido em vida pelo autor da herança.
Para tal situação, o ordenamento oferece remédios como a ação de petição de herança e a ação de investigação de filiação, que poderão ser manejadas pelo filho para que veja declarada sua condição de herdeiro e, por corolário, alcance seu quinhão.

Há de ser observado, por fim, o prazo prescricional, que, embora não atinja a ação de investigação de paternidade, tem o condão de fulminar a pretensão de herança.

\section{DA FILIAÇÃO SOCIOAFETIVA}

\subsection{Filiação Biológica e Filiação Socioafetiva}

A Constituição Federal, em seu art. 227, $\S 6^{\circ}$, exara que os filhos têm os mesmos direitos, proibindo qualquer distinção e/ou discriminação entre eles, interpretando-se que 
desimporta o modo de constituição e reconhecimento da filiação.

O Código Civil de 2002, em linhas gerais, assumiu a absoluta igualdade dos filhos e a ausência de restrições na pesquisa da verdadeira paternidade biológica. A grande falha encontrada nesse Codex é não ter sido criado critério para a verdade socioafetiva, cada vez mais presente nas relações entre pais e filhos, como único vínculo estabelecido.

Além da paternidade biológica, mantém o Código de $2002^{1}$ a paternidade legal ou presumida pelo simples fato do nascimento, com a finalidade de preservar ao máximo a família como estrutura básica e ética da sociedade constitucionalmente protegida. Essa presunção estabelecida pela lei é juris tantum, cedendo mediante prova da não relação biológica entre a criança e o suposto pai, sendo essa ação imprescritível. ${ }^{2}$ Há quem entenda ser de natureza mista. Tendo algo de absoluta sem ser absoluta, admitindo prova em contrário como as relativas, porém com excepcionalidades, pois cria um ônus de prova para o pai que pretenda contestar a paternidade.

Essa presunção é cada vez mais discutida em juízo em razão da busca da verdade biológica.

Se de um lado houve uma proteção ao filho biológico no atual Código Civil, podendo o filho investigar sua origem biológica, e sendo esta ação imprescritível, nada constou acerca da possibilidade de investigar a paternidade ou maternidade socioafetiva quando esta não estiver de direito estabelecida, isto é, quando não houver registro de nascimento constando os pais socioafetivos.

1 Art. 1.597. Presumem-se concebidos na constância do casamento os filhos:

I - nascidos cento e oitenta dias, pelo menos, depois de estabelecida a convivência conjugal;

II - nascidos nos trezentos dias subsequentes à dissolução da sociedade conjugal, por morte, separação judicial, nulidade e anulação do casamento;

III - havidos por fecundação artificial homóloga, mesmo que falecido o marido;

IV - havidos, a qualquer tempo, quando se tratar de embriões excedentários, decorrentes de concepção artificial homóloga;

$\mathrm{V}$ - havidos por inseminação artificial heteróloga, desde que tenha prévia autorização do marido.

2 Art. 1.601. Cabe ao marido o direito de contestar a paternidade dos filhos nascidos de sua mulher, sendo tal ação imprescritível.

Parágrafo único. Contestada a filiação, os herdeiros do impugnante têm direito de prosseguir na ação. 
A doutrina amplamente demonstra a posse do estado de filho como uma das possibilidades de paternidade fática. Assim nasce a posse do estado de filho quando as pessoas desfrutam de uma situação jurídica que não corresponde à verdade, mas a aparência faz com que todas as pessoas acreditem existir situação não verdadeira, fato que não pode ser desprezado pelo direito. Nesse caso surge a teoria da aparência, que no caso da filiação nasce com o vínculo da paternidade, isto é, a realidade corresponde a uma aparente relação paterno-filial. Nessa seara encontra-se a filiação socioafetiva, isto é, no reconhecimento da posse do estado de filho que traz a condição de filho fundada em laços de afeto.

Segundo Maria Berenice Dias, para que haja o reconhecimento da posse do estado de filho, deverá haver a conjunção de três aspectos: tractatus - quando o filho é tratado como tal, criado e educado e apresentado como filho pelo pai e mãe; nominatio - usa o nome da família e assim se apresenta; e reputatio - é conhecida pela opinião pública como pertencente à família de seus pais. Há verossimilhança à aparência e assim o direito considera satisfatória. $^{3}$

Qualquer meio de prova admitido em direito pode ser utilizado para comprovar o estado de filiação. Entende-se, contudo, que deverá haver começo de prova documental proveniente dos pais, ou presunções veementes que demonstrem a situação fática construída.

A doutrina considera, como início de prova por escrito dos pais, cartas, declaração de filiação para fins de imposto de renda e anotações dando conta do nascimento do filho.

Assim a paternidade e maternidade biológica nada valem diante do vínculo afetivo que se forma entre a criança e aquele que trata e cuida dela, participando fatica e afetivamente da sua vida.

Claramente se vislumbra que a Constituição Federal abandonou a primazia da origem biológica, quando equiparou os filhos naturais e os adotados atribuindo a prioridade absoluta à convivência familiar. ${ }^{4}$

Conclui-se que a posse do estado de filho consolidada no tempo predomina sob o critério biológico, impedindo o exercício de impugnar a paternidade baseada no critério genético. ${ }^{5}$

3 DIAS, Maria Berenice. Manual de Direitos das Famílias. Porto Alegre: Livraria do advogado, 2005, p. 340.

4 LÔBO, Paulo. Direito Civil - Famílias. São Paulo: Saraiva, 2012, p 227.

5 LÔBO, Paulo. Direito Civil - Famílias. São Paulo: Saraiva, 2012, p 238. 


\subsection{Critérios para estabeleci- mento da paternidade/materni- dade ou filiação}

Segundo Edson Fachin, existem três critérios para estabelecimento da paternidade, maternidade ou filiação, sendo estes a verdade legal, verdade biológica e verdade socioafetiva. ${ }^{6}$

Até a Constituição de 1988 prevalecia o critério legal, ou seja, era filho aquele que a lei determinava, mesmo que todos soubessem que não era o filho biológico daqueles que figuram como pai ou mãe.

No Código Civil de 1916, havia prazos decadenciais curtíssimos para que o marido contestasse a paternidade.

No Código de 2002, há a predominância da verdade biológica estabelecendo inclusive a imprescritibilidade da possibilidade de contestar a paternidade. ${ }^{7}$ Porém, com o passar dos tempos, coube à doutrina e à jurisprudência estabelecer critérios para ajustar a possibilidade de contestação da paternidade para não criar insegurança jurídica nas relações familiares.

Ainda na vigência do Código de 1916 era possível atenuar o critério da verdade legal. Segundo Caio Mário da Silva Pereira, havia a possibilidade de ação de impugnação ou desconhecimento da paternidade que poderia ser ajuizada quando havia falta de identidade entre a criança nascida da mulher e a pessoa que traz a condição de filho, nos casos de simulação de parto, falsidade ideológica ou instrumental do assento de nascimento. Essa ação era imprescritível e poderia ser ajuizada tanto pelo pai como pela mãe.

Tem-se como certo que todas as ações de estado são imprescritíveis, porém as consequências jurídicas decorrentes dessas ações podem sofrer algumas restrições.

No entanto, ainda que imprescritível, a pretensão impugnativa será exercida não só pela prova da inexistência do vínculo biológico, mas deve-se incluir a ausência de vínculo socioafetivo.

\subsection{Critério socioafetivo}

Não há referência expressa no Código Civil acerca desse critério, porém tanto a doutrina quanto a jurisprudência entendem estar presente em nosso sistema jurídico, sendo que a própria Constituição Federal em seu art. 227, $\S 6^{\circ}$, proíbe qualquer distinção entre os filhos, independente do critério.

6 FACHIN, Luiz Edson. Da paternidade - relação biológica e afetiva. Belo Horizonte: Del Rey Editora, 1996.

7 Art. 1.601 CC - Cabe ao marido o direito de contestar a paternidade dos filhos nascidos de sua mulher, sendo tal ação imprescritível. 
O texto constitucional abrange as vertentes sociológicas das novas famílias, incluindo-se, então, o critério socioafetivo.

A relação socioafetiva entre filho e pai ou mãe não pode simplesmente se presumir pela passagem do tempo, é preciso averiguar se existe ou não a relação socioafetiva. É preciso que realmente haja uma relação baseada no afeto para que seja caracterizada.

\subsection{Investigação de paternidade}

Conforme previsto na Lei $8.560 / 92$, pode o filho ingressar com ação de investigação de paternidade para buscar sua verdade biológica, independente que esteja registrado em nome de outra pessoa.

No Código Civil há previsão da possibilidade de o pai contestar a paternidade de seu filho, na busca da verdade biológica, conforme prevê o art. 1.601, sendo tal ação imprescritível. ${ }^{8}$ Tal previsão visa desconstituir o vínculo entre pai e filho decorrente da presunção legal de paternidade (pater is est).
Pode ainda o registro de nascimento decorrer de adoção ou falsidade, não havendo vedação para que o investigante promova a investigação de sua paternidade.

Para que os efeitos constitutivos da ação sejam alcançados, no que se refere à bsuca do reconhecimento da paternidade, é necessário que se comprove a inexistência da paternidade socioafetiva, em razão desta prevalecer sobre qualquer outro vínculo paterno filial. Dessa forma, segundo entendimento dominante na doutrina e jurisprudência atual, deve-se ampliar o objeto litigioso para além da busca da verdade biológica, a busca da não existência de vínculo de filiação gerador da posse do estado de filho. ${ }^{9}$

Em relação à imprescritibilidade da ação de investigação de paternidade, se deve entender que o art. 1.614 do Código Civil não pode ser aplicado, pois o prazo de quatro anos estabelecido pela lei civil para impossibilitar a investigação de paternidade do filho nascido na constância do matrimônio estaria dando tratamento desigual em relação aos demais filhos. ${ }^{10}$

8 Art. 1.601. Cabe ao marido o direito de contestar a paternidade dos filhos nascidos de sua mulher, sendo tal ação imprescritível.

Parágrafo único. Contestada a filiação, os herdeiros do impugnante têm direito de prosseguir na ação.

9 Segundo Maria Berenice Dias, a verdade socioafetiva deve prevalecer sobre os demais critérios da filiação. DIAS, Maria Berenica. Manual de Direitos das Famílias. Porto Alegre: Livraria dos Advogados, 2003.

10 Art. 1.614. O filho maior não pode ser reconhecido sem o seu consentimento, e o menor pode impugnar o reconhecimento, nos quatro anos que se seguirem à maioridade, ou à emancipação. 
O Tribunal de Justiça do Rio Grande do Sul aplica esse prazo apenas nos casos de reconhecimento em que o filho pretenda somente desconstituí-lo, mas não nos casos em que o filho pretenda a declaração da paternidade e o cancelamento do registro civil existente.

O entendimento atual é a possibilidade de investigação da paternidade a qualquer tempo, sendo essa ação imprescritível, porém encontrando como única barreira para alteração do estado de filiação a preexistência de paternidade socioafetiva.

Havendo um vínculo de afeto entre o pai e o filho, nem um nem outro poderá romper esse vínculo apenas por não corresponder ao critério biológico.

1.5 Do direito à origem genética como direito de personalidade, sem vínculo com o estado de filiação

O estado de filiação decorre dos vínculos afetivos desenvolvidos entre pai e filho e constitui fundamento para atribuição da paternidade e maternidade.

De outra banda, o direito ao conhecimento da origem genética decorre do direito de personalidade.

Poder-se-ia distinguir o pai como aquele que cria, e o genitor como aque- le que gera. Esses conceitos estiveram unidos enquanto houve a primazia da função biológica da família, porém hoje a família é muito mais que questões biológicas, pois há prevalência do afeto nas relações estabelecidas.

Assim, independente de estar estabelecida uma filiação socioafetiva, se deve entender como possível o conhecimento da origem biológica da pessoa sem qualquer alteração no estado de filiação já estabelecido.

Para justificar a possibilidade de conhecimento da origem genética, deve-se pensar nas realidades da ciência para preservação da saúde e da vida. Assim, aquele que conhece sua origem genética poderá tomar certas precauções acerca de possíveis doenças e tratamentos.

A causa de pedir nessas ações é o fato da concepção decorrente do contato sexual entre os genitores. É preciso ainda reequacionar a distribuição do ônus probatório feito pelo art. 333 do CPC. Ao Autor, atualmente, cabe a demonstração da possível relação íntima entre sua mãe e o suposto pai, e a este provar por meio do exame de DNA, que é uma prova pericial, que não há vínculo biológico com o Autor.

Atualmente há súmula no STJ prevendo que a negativa do suposto pai em submeter-se ao exame de DNA gera presunção juris tantum de paternidade. ${ }^{11}$

11 Súmula 301 STJ - Em ação de investigatória, a recusa do suposto pai a submeter-se ao exame de DNA induz presunção juris tantum de paternidade. 
Mesmo com a recusa do suposto pai, cabe ao investigante provar minimamente com provas indiciárias a existência do relacionamento íntimo entre sua mãe e o investigado.

Ausente a paternidade socioafetiva entre o investigante e outra pessoa, a procedência da ação de investigação de paternidade alterará a filiação, criando um vínculo de direito de família entre autor e réu. E no caso de o pai ser falecido, o direito sucessório em relação à herança deixada pelo pai.

Presente a paternidade socioafetiva, a prova do vínculo biológico apenas gerará a certeza quanto à origem genética do investigante, não modificando qualquer vínculo de filiação previamente estabelecido.

Pode-se dizer que o vínculo de afeto existente entre pai e filho previamente estabelecido prevalece em relação ao vínculo biológico.

Recentes julgados do Tribunal de Justiça do Rio Grande do Sul:

APELAÇÃO CÍVEL. INVESTIGAÇÃO DE PATERNIDADE. EXISTÊNCIA DE PAI REGISTRAL. PATERNIDADE SOCIOAFETIVA. AUSÊNCIA DE VÍCIOS DE CONSENTIMENTO. O reconhecimento da paternidade é ato irrevogável, a teor do art. $1^{\circ}$ da Lei no 8.560/92 e art. 1.609 do Código Civil. A retificação do registro civil de nascimento, com supressão do nome do genitor, somente é possível quando há nos autos prova cabal de ocorrência de vício de consentimento no ato registral ou, em situação excepcional, demonstração de cabal ausência de qualquer relação socioafetiva entre pai e filho. Estando demonstrada nos autos a filiação socioafetiva, a paternidade impera sobre a verdade biológica. RECURSO DESPROVIDO. (Apelação Cível N ${ }^{\circ}$ 70045006293, Sétima Câmara Cível, Tribunal de Justiça do RS, Relator: Liselena Schifino Robles Ribeiro, Julgado em 11/04/2012).

AGRAVO DE INSTRUMENTO. AÇÃO DE INVESTIGAÇÃO DE PATERNIDADE CUMULADA COM PETIÇÃO DE HERANÇA. GRATUIDADE DE JUSTIÇA. DETERMINAÇÃO DE COMPROVAÇÃO DA NECESSIDADE. CABIMENTO. Havendo circunstâncias que autorizem, ao juiz é possível determinar que a parte postulante do benefício da gratuidade de justiça comprove sua incapacidade financeira, a fim de que possa ser feito juízo de valor sobre se se trata, efetivamente, de parte necessitada. RESERVA DE BENS. A reserva de bens é medida cautelar sujeita aos requisitos do fumus boni iuris e do periculum in mora, visando garantir o resultado útil de eventual procedência de ação de investigação de paternidade. Presentes os requisitos necessários ao deferimento da medida. Agravo de instrumento parcialmente provido. (Agravo de Instrumento $\mathrm{N}^{\circ}$ 70045704665, Sétima Câmara Cível, Tribunal de Justiça do RS, Relator: Jorge Luís Dall’Agnol, Julgado em 11/04/2012).

APELAÇÃO CÍVEL. INVESTIGAÇÃO DE PATERNIDADE. Possibili- 
dade jurídica do pedido. O pedido do autor é para que seja reconhecida a relação de filiação entre ele e o réu. Logo, não importa quem é sua mãe biológica, registral ou socioafetiva. O que importa é que esse pedido encontra expresso amparo legal no art. 1.606 do Código Civil, sendo, portanto, juridicamente possível. Prescrição. A partilha realizada sem a participação de herdeiro necessário padece de nulidade absoluta, a qual não convalesce com o tempo e não se sujeita aprazo decadencial ou mesmo prescricional. Litisconsórcio necessário. Embora todos os herdeiros do investigado sejam litisconsortes passivos necessários na ação de investigação de paternidade proposta contra o autor da herança, a questão vai superada nos termos do art. 249, $\S 2^{\circ}$, do CPC, segundo o qual, "Quando puder decidir do mérito a favor da parte a quem aproveite a declaração da nulidade, o juiz não a pronunciará nem mandará repetir o ato, ou suprir-lhe a falta.” A paternidade. $\mathrm{O}$ autor viveu mais de cinquenta anos como sendo filho de seu pai registral, recebeu dele a herança e nunca teve contato com seu pai biológico. Logo, apesar de o exame de DNA ter demonstrado que o autor é filho biológico do réu, essa paternidade biológica não se sobrepõe à posse do estado de filho ostentado pelo autor durante toda a sua vida e que passou a fazer parte de sua identidade. REJEITARAM AS PRELIMINARES. DERAM PROVIMENTO. (Apelação Cível No 70046254868, Oitava Câmara Cível, Tribunal de Justiça do RS, Relator: Rui Portanova, Julgado em 29/03/2012).
APELAÇÃO CÍVEL. INVESTIGAÇÃO DE PATERNIDADE. PROCESSO EXTINTO POR IMPOSSIBILIDADE JURÍDICA DO PEDIDO SOB ALEGAÇÃO DE EXISTÊNCIA DE PATERNIDADE SOCIOAFETIVA COM O PAI REGISTRAL. DESCABIMENTO. $1 . \mathrm{O}$ pedido formulado na inicial é juridicamente possível, uma vez que a existência de paternidade socioafetiva - sequer invocada pelo réu - somente é oponível pelo próprio filho, contra aquele que o reconheceu voluntariamente como tal e resolve postular a revogação do reconhecimento, salvo comprovado erro. 2. Mesmo que se tenha configurado a paternidade socioafetiva do apelado para com o reconhecente, tal não é óbice à pretensão do autor de investigar sua origem biológica e ver constituído o vínculo de paternidade com seu verdadeiro pai, com todas as consequências jurídicas decorrentes. DERAM PROVIMENTO. UNÂNIME. (Apelação Cível $\mathrm{N}^{\circ}$ 70045514791, Oitava Câmara Cível, Tribunal de Justiça do RS, Relator: Luiz Felipe Brasil Santos, Julgado em 29/03/2012).

APELAÇÃO CÍVEL. AÇÃO DE INVESTIGAÇÃO DE PATERNIDADE CUMULADA COM NULIDADE DE PARTILHA E PETIÇÃO DE HERANÇA. PAI FALECIDO. COISA JULGADA. PRESCRIÇÃO. EXAME DE DNA REALIZADO COM AMOSTRAS DE SANGUE DE UM FILHO BIOLÓGICO DO SUPOSTO PAI. PROBABILIDADE DE PATERNIDADE SUPERIOR A 99,95\%, INDICANDO QUE O 
AUTOR PERTENCE À MESMA LINHAGEM DO INVESTIGADO. Tratando-se de investigação de paternidade, não há coisa julgada sem exame de DNA, porquanto os efeitos da coisa julgada, em ações de investigação de paternidade, sofrem alguma distensão, em face da possibilidade de um juízo de certeza advinda dos avanços do DNA. Resultado do exame de DNA que é conclusivo no sentido de afirmar a paternidade, nada aportando aos autos para inquinar a idoneidade do respectivo laudo. RECURSO DESPROVIDO. (Apelação Cível N N 70046265674, Sétima Câmara Cível, Tribunal de Justiça do RS, Relator: Liselena Schifino Robles Ribeiro, Julgado em 28/03/2012).

APELAÇÃO CÍVEL. AÇÃO DE INVESTIGAÇÃO DE PATERNIDADE CUMULADA COM DESCONSTITUIÇÃO DE REGISTRO DE PATERNIDADE. ALEGAÇÃO DE CERCEAMENTO DE DEFESA. JUNTADA DE DOCUMENTOS. POSSIBILIDADE A QUALQUER TEMPO. INEXISTÊNCIA DE OFENSA AOS PRINCÍPIOS DA AMPLA DEFESA E CONTRADITÓRIO. DECADÊNCIA. DESCABIMENTO. A pretensão à declaração da paternidade é imprescritível. A regra do art. 1.614 do Código Civil só é aplicável ao filho que pretende apenas desconstituir o reconhecimento da filiação, mas não aquele que busca a declaração da paternidade e o cancelamento do registro civil existente. Precedentes do STJ. PATERNIDADE SOCIOAFETIVA. AUSÊNCIA DE PROVA. Inexistente nos autos prova da relação de afetividade entre as partes, não há vingar a tese de paternidade socioafetiva da apelada com o pai registral. EXAME DE DNA. NÃO COMPARECIMENTO DO INVESTIGADO. PRESUNÇÃO JURIS TANTUM DE PATERNIDADE. A recusa imotivada do investigado em submeter-se ao exame de DNA gera presunção juris tantum de paternidade. Caracterizado o desinteresse do investigado em produzir prova essencial ao deslinde da ação, não havendo prova em sentido contrário, imperioso reconhecer a paternidade. Apelação desprovida, de plano. (Apelação Cível Nº 70045399300, Sétima Câmara Cível, Tribunal de Justiça do RS, Relator: Jorge Luís Dall’Agnol, Julgado em 23/03/2012).

Destarte, segundo Paulo Lôbo, o direito ao reconhecimento genético está ligado a que toda pessoa humana é titular do direito à vida. Em relação à saúde, as ciências biológicas têm salientado a importância desse conhecimento em razão da prevenção da ocorrência de doenças que poderiam acometer os parentes biológicos com possibilidade de igualmente acometerem aquele que possui vínculo genético. ${ }^{12}$ 


\section{DA AÇÃO DE PETIÇÃO DE HERANÇA}

É muito recorrente que o filho socioafetivo seja preterido em sua posição de herdeiro legítimo, em razão de ainda não ter sido legalmente declarada sua condição de filho.

Para reparar situações como essa, o Código Civil, em seu Livro V, Capítulo VII, artigos 1.824 a 1.828 , prevê a ação de petição de herança, no intuito de alcançar ao herdeiro filho o quinhão que lhe cabe.

\subsection{Breve noção histórica}

Segundo Paulo Nader ${ }^{13}$, a origem histórica da ação petição de herança encontra-se no Direito Romano, sob a denominação hereditatis petitio ou vindicatio generalis. Sua finalidade era proteger o quinhão do herdeiro legítimo ou testamentário quando preterido por outro herdeiro (este chamado de possuidor pro herede), ou por quem não possuía qualquer título (chamado de possuidor pro possessor), inclusi- ve o que adquiria a posse por violência ou subtraindo a coisa alheia.

Nesse panorama, a parte legitimada a intentar a ação era apenas aquela que se intitulava sucessor legítimo ou testamentário, a quem, por conseguinte, cumpria a prova de sua qualidade de herdeiro. Cabe salientar que, posteriormente, a ação também foi permitida àqueles que se achavam em situação análoga à de herdeiro.

A princípio, o herdeiro aparente ${ }^{14}$ (possessor pro herede) era o sujeito passivo da ação. Mais tarde, também tornou-se possível propor a ação em face daquele que mantinha a posse do bem, sem, no entanto, alegar a condição de herdeiro (possessor pro possessore).

Nader refere ainda que o Direito Comparado registra três sistemas no tocante à petição de herança ${ }^{15}$ :

Alguns Códigos, entre os quais o
francês, o português, o argentino, se
limitam a uma ou outra disposição
dispersa. O código de Beviláqua,
considerando-se as regras do pará-
grafo único do art. 1.580 e art. 1.600,
seguia tal orientação.

13 NADER, Paulo. Curso de Direito Civil. V. 6: direito das sucessões. Rio de Janeiro: Forense, 2007, p. 156.

14 "Herdeiro aparente vem a ser o que, não titular de direito sucessório, é tido, entretanto, como legítimo proprietário da herança.” ALMADA, Ney de Mello. Direito das Sucessões. Editora Brasiliense. TOMO I, p. 226.

15 NADER, Paulo. Curso de Direito Civil. V. 6: direito das sucessões. Rio de Janeiro: Forense, 2007, p. 153. 
Para outros sistemas, ao qual se filiam os Códigos brasileiro, holandês, chileno, austríaco, a petição de herança é objeto de uma regulamentação sumária, não exaustiva. Finalmente, há os Códigos, como o alemão, o suíço e o peruano, que se dedicam amplamente à matéria.

No ordenamento pátrio, o Código de Beviláqua pouco tocou no tema ${ }^{16}$, embora a ação fizesse parte da prática forense. Já o atual código, debruça esforço de um capítulo sobre a matéria, do art. 1.824 ao art. 1.828 , sem, contudo, exauri-la.

\subsection{Conceito e aspectos processuais}

Arnaldo Rizzardo ${ }^{17}$ ensina que a ação de petição de herança é um modo de defender e impor o título hereditário aos casos em que algum herdeiro tenha sido excluído do inventário e da parti- lha. Tal instrumento processual garante nada menos do que a efetividade do princípio da transmissão imediata da posse e do domínio, denominado princípio da saisine.

Acrescenta-se que a ação de petição de herança visa garantir a eficácia de um direito fundamental previsto expressamente no art. $5^{\circ}$, $\mathrm{XXX}^{18}$, da CF.

No plano infraconstitucional, o artigo 1.824 do Código Civil dispõe: "O herdeiro pode, em ação de petição de herança, demandar o reconhecimento de seu direito sucessório, para obter a restituição da herança, ou parte dela, contra quem, na qualidade de herdeiro, ou mesmo sem título, a possua."

Assim, pela petição de herança, o herdeiro busca o reconhecimento judicial de seu direito sucessório para poder alcançar a parte do quinhão que lhe cabe, contra quem o possui ${ }^{19}$.

16 No Código Civil de 1916, a petição de herança fundava-se no art. 1.580, parágrafo único: "Qualquer dos coerdeiros pode reclamar a universalidade da herança ao terceiro, que indevidamente a possua, não podendo este opor-lhe, em exceção, o caráter parcial do seu direito nos bens da sucessão.”

17 RIZZARDO, Aranaldo. Direito das Sucessões: Lei n. 10.406, de 10.01.2002. Rio de Janeiro: Forense, 2008, p. 131.

18 É garantido o direito de herança.

19 “A demanda do presumido herdeiro em torno da herança pode ocorrer fundamentalmente contra terceiro estranho à vocação hereditária; contra herdeiro aparente ou quem indevidamente se arvora herdeiro ou contra herdeiro que pretende parcela maior daquela que lhe é devida.” VENOSA, Sílvio de Salvo. Direito Civil: direito das sucessões. $6^{\mathrm{a}}$ edição. São Paulo: Atlas, 2006, p. 102. 
Explica Zeno Veloso ${ }^{20}$ quem é o réu da ação de petição de herança:

O réu é a pessoa que não tem título legítimo de herdeiro e, não obstante, possui bens da herança total ou parcialmente [...] ou seja, no polo passivo desta ação está o falso herdeiro, ou o que possui a herança, ou parte dela, sem título algum

Alguns autores ${ }^{21}$ sustentam a existência de duas ações distintas, uma para cada pedido, quais sejam, o reconhecimento da qualidade de herdeiro e a restituição de bens. Em contrapartida, esclarece Venosa ${ }^{22}$ : “A ação de petição de herança objetiva não somente o reconhecimento da qualidade de herdeiro, mas também e principalmente sua integral satisfação no tocante ao acervo hereditário”.
Ou seja, embora se exija a prova da qualidade de herdeiro, o intuito final do autor na ação de petição de herança é alcançar seu direito de posse ou propriedade. Daí tratar-se de ação que será resolvida, em caso de procedência, por sentença com eficácia predominantemente condenatória, o réu será compelido à entrega do quanto possua indevidamente ${ }^{23}$.

A ação de petição de herança, em que pesem as semelhanças, não se confunde com a ação reivindicatória. Aquela se particulariza exatamente pelo pressuposto do reconhecimento da condição de herdeiro, além do que tem como fundamento a herança em sua universalidade (art. 1.825, CC). Esclarece Rizzardo ${ }^{24}$ :

Distingue-se substancialmente da reivindicatória, em vista de que, nesta,

20 VELOSO, Zeno. Novo Código Civil Comentado. Coord. Ricardo Fiúza. São Paulo: Saraiva, 2006, p. 1.521.

21 "Entendem alguns, citando-se, por todos, Carvalho Santos, que a petitio hereditatis possui natureza mista, compondo-se assim o raciocínio que sustenta tal doutrina: dois segmentos encerra o tema, o inicial exibindo índole eminentemente pessoal, por que se destina à apuração do título hereditário, ao passo que o segundo, de natureza real, guarda pertinência com a reivindicação universal do patrimônio.

Outros advogam que se cuida de ação pessoal, em seu exercício pondo-se em jogo apenas o título hereditário.

Um terceiro elenco de opinião a entende como ação real, e a este nos incorporamos. A herança é considerada bem imóvel, sendo uma universalidade de bens [...]”. ALMADA, Ney de Mello. Direito das Sucessões. Editora Brasiliense. TOMO I, p. 229.

22 VENOSA, Sílvio de Salvo. Direito Civil: direito das sucessões. $6^{a}$ edição. São Paulo: Atlas, 2006, p. 103.

23 ALMADA, Ney de Mello. Direito das Sucessões. Editora Brasiliense. TOMO I, p. 229. 24 RIZZARDO, Aranaldo. Direito das Sucessões: Lei n. 10.406, de 10.01.2002. Rio de Janeiro: Forense, 2008, p. 13 
procura o titular do direito o reconhecimento do próprio bem, enquanto na petição de herança persegue-se 0 quinhão, às vezes sem especificar os bens.

O objeto, aliás, da petição centralizase na busca do quinhão - nem sempre individuável, diferentemente do que se dá com a reivindicatória. Tem a petição de herança caráter universal, visando o pretendente o reconhecimento de seu direito sobre a universalidade da herança.

Não é demais dizer que a ação de petição de herança tem como título a qualidade hereditária, enquanto a ação reivindicatória tem a propriedade.

Cabe ressaltar ainda que, exatamente por ter a possibilidade de buscar algo indeterminado ${ }^{25}$, a herança enquanto universalidade, a ação de petição de herança não se presta à tutela dos direitos do legatário, que não integra a categoria de herdeiro. É nesse sentido a doutrina de Almada ${ }^{26}$ :
Além de real, trata-se de ação universal. $\mathrm{O}$ autor não visa a um bem certo e determinado, como coisa singular e individualizada, senão a uma universalidade, que, a rigor, constitui o fundamento e não, propriamente, o objeto da ação. Daí não configurar irrisão alguma o ônus, imputado ao autor, de provar que coisa ou coisas possuídas pertenciam ao de cujus, ao lado de patentear que é herdeiro.

Tal ação pode ser ajuizada antes ou após a sentença de partilha e o autor deve provar sua condição de herdeiro legítimo ou testamentário. Como refere Almada ${ }^{27}$, a prova da qualidade de herdeiro pode ser pré-constituída ou ser deduzida no curso da ação, como no caso de cumulação com a ação de investigação de paternidade, esta como prejudicial lógica daquela.

É recorrente a cumulação das ações de investigação de filiação e petição de herança, que, entretanto,

25 Conforme salientado em capítulo próprio, a herança é um todo uno e indivisível, aplicando-se as regras relativas ao condomínio até que ocorra a partilha (art. 1.791 do CC). Assim sendo, a ação de petição de herança, ainda que exercida por um só dos herdeiros, poderá compreender todos os bens hereditários (art. 1.825 do CC). É semelhante à regra presente no condomínio, pela qual qualquer um dos condôminos tem o direito de defender a coisa como um todo, mesmo sendo titular de apenas parte dela. Perante terceiros, que não os demais condôminos (no caso, coerdeiros), cada herdeiro age como se fosse proprietário exclusivo do todo. TARTUCE, Flávio; SIMÃO, José Fernando. Direito Civil. V. 6: direito das sucessões. 5. Ed. rev. e atual. São Paulo: Método, 2012, p. 103. 26 ALMADA, Ney de Mello. Direito das Sucessões. Editora Brasiliense. TOMO I, p. 229. 27 ALMADA, Ney de Mello. Direito das Sucessões. Editora Brasiliense. TOMO I, p. 226. 
não se confundem. A primeira é ação de estado e a segunda tem cunho patrimonial. Leciona $\mathrm{Nader}^{28}$ :

A investigatória constitui, em muitos casos, um instrumento para se lograr a procedência da petição de herança. Por ela o requerente visa ao certificado de sua filiação, enquanto pela outra o objetivo é o reconhecimento do direito hereditário, cujo resultado prático deve ser a entrega, pelo réu, da herança como um todo ou quota-parte. A sentença na ação de petição de herança, enquanto vise à restituição de bens, é condenatória; já na investigação, é de natureza declaratória. No tocante ao reconhecimento da qualidade de herdeiro a sentença contém declaração.

Nader $^{29}$ chama a atenção para a legitimidade ativa. A ação deve ser ajuizada necessariamente por quem se diz herdeiro, e nessa condição, o espólio não possui legitimidade para tanto. Ainda que o espólio seja dotado de capacidade judiciária, o interesse de agir é somente do herdeiro. E refere: "os situados em classe sucessória imediatamente inferior à do herdeiro renunciante possuem legitimidade para a ação, uma vez que assumem a condição de sucessores”.

Igualmente importante é a questão relativa aos frutos produzidos pelo acervo hereditário e à indenização pelas benfeitorias realizadas no bem.

A resposta para essas questões está no art. 1.826, CC, segundo o qual, tudo dependerá da boa ou máfé do herdeiro possuidor. Dispõe o referido artigo que

o possuidor da herança está obrigado à restituição dos bens do acervo, fixando-se-lhe a responsabilidade segundo a sua posse, observado o disposto nos arts. 1.214 a 1.222.

Parágrafo único. A partir da citação, a responsabilidade do possuidor se há de aferir pelas regras concernentes à posse de má-fé e à mora.

Segundo se pode interpretar, a boa-fé refere-se à ignorância de uma situação, ou seja, “desconhece o sujeito que perdeu a qualidade de herdeiro, e se trata, portanto, de boa-fé subjetiva [...]. Vale repetir que a boa-

28 Nader, citando Francesco Massineo, refere: “A petição de herança é ação de condenação, enquanto tende a obter a restituição de bens hereditários possuídos por outros, mas pode ser também ação de declaração positiva de certeza da qualidade de herdeiro. A petição assume este segundo e menos pleno aspecto, quando esteja em discussão a qualidade de herdeiro, mas não existia também posse de bens hereditários por parte de um não herdeiro.” NADER, Paulo. Curso de Direito Civil. V. 6: direito das sucessões. Rio de Janeiro: Forense, 2007, p. 163.

29 NADER, Paulo. Curso de Direito Civil. V. 6: direito das sucessões. Rio de Janeiro: Forense, 2007, p. 158-159. 
-fé cessa com a citação do réu na ação de petição de herança e, a partir de então, devem ser aplicadas as regras referentes à má-fé."30

O foro para a propositura da ação é o da comarca em que tramita o inventário. Caso a partilha já tenha sido realizada, o ajuizamento deverá ocorrer no lugar onde o réu estiver domiciliado. Se houver mais de um réu, dada a divisão da universalidade dos bens, ocorrerá litisconsórcio passivo necessário ${ }^{31}$ e o foro será fixado pelas regras gerais de competência.

\subsection{Prescrição}

No plano doutrinário, há anos, autores divergem acerca da imprescritibilidade, ou não, da petitio hereditatis.

Orlando Gomes defendia a imprescritibilidade da ação, nos seguintes termos:

No rigor dos princípios, a ação é imprescritível. Ainda que tivesse na- tureza real, não prescreveria, como não prescreve a ação de reivindicação, a que se equipararia. Fosse ação pessoal, também seria imprescritível porque, destinada ao reconhecimento da qualidade hereditária de alguém, não se perde esta pelo não uso. Busca-se um título de aquisição. Seu reconhecimento não pode ser trancado pelo decurso do tempo. Há de ser declarado, passem ou não os anos. ${ }^{32}$

Assim, o herdeiro aparente, que está na posse dos bens, pode usucapir os bens que lhe foram alcançados, utilizando-os na convicção de que lhe pertenciam. Nesse caso, não é que a petitio hereditatis prescreveria, mas se tornaria inútil diante do título adquirido pela usucapião.

Ney de Mello Almada também traz à baila o raciocínio da ação reivindicatória para dizer que a seu respeito é apenas cogitável a usucapião. Pois a ação de petição de herança, “[...] irmanada à propriedade, participaria da mesma sorte da reivindicatória, escapando à fulminação prescricional." ${ }^{\text {33 }}$

30 TARTUCE, Flávio; SIMÃO, José Fernando. Direito Civil. V. 6: direito das sucessões. 5. Ed. rev. e atual. São Paulo: Método, 2012, p. 104 e 105.

31 Art. 94, CPC: A ação fundada em direito pessoal e a ação fundada em direito real sobre bens móveis serão propostas, em regra, no foro do domicílio do réu.

$\S 4^{\circ}$ Havendo dois ou mais réus, com diferentes domicílios, serão demandados no foro de qualquer deles, à escolha do autor.

32 GOMES, Orlando. Sucessões. $12^{\mathrm{a}}$ ed. rev., atual e aumentada de acordo com o Código Civil de 2002, por Mario Roberto Carvalho de Faria. Rio de Janeiro: Forense, 2004, p. 265.

33 ALMADA, Ney de Mello. Direito das Sucessões. Editora Brasiliense. TOMO I, p. 236. 
Mais atualmente, Hironaka busca o reconhecimento da filiação. comunga da mesma opinião de Para a ação de petição de herança, tenOrlando Gomes, defendendo que "a petição de herança não prescreve. A ação é imprescritível, podendo, por isso, ser intentada a qualquer tempo. Isso sim se passa porque a qualidade de herdeiro não se perde (semel heres, semper heres)"34

Esse é igualmente o pensamento de Tartuce $^{35}$, pois entende que a ação de petição de herança tem caráter predominantemente declaratório, o qual envolve, ainda, o direito fundamental à herança, previsto no art. $5^{\circ}, \mathrm{XXX}$, da $\mathrm{CF} / 88$.

Sobre o entendimento, relembra Veloso $^{36}$ que o anteprojeto revisto de 1972 dispunha nesse sentido: “a petição de herança é imprescritível, ressalvadas as regras sobre usucapião relativamente a cada um dos bens singulares do acervo.”

De outra parte, Caio Mário ${ }^{37}$, entretanto, reconhece como imprescritível apenas a ação de estado, a qual do em vista seu cunho econômico, reconhece a prescrição de 10 anos, pela regra geral do art. 205 do novel CC.

Assim também é a lógica de Simão $^{38}$. Ele entende que a ação de petição de herança tem conteúdo condenatório evidente:

Sendo dotada de pedido de dar entrega de bens que compõem o acervo hereditário -, existe uma pretensão, que se extingue pela prescrição (art. 189 do CC). Em outras palavras, pode-se dizer que a pretensão é a possibilidade conferida ao credor, autor da ação de petição de herança, de exigir do devedor, réu da ação, o cumprimento da prestação (entrega dos bens).

No campo jurisprudencial, a Súmula 149, do Supremo Tribunal Federal, definiu o tema dizendo que "É imprescritível a ação de investigação de paternidade, mas não o é a de petição de herança."

34 HIRONAKA, Giselda Maria Fernandes Novaes. Comentários ao Código Civil. 2. ed. AZEVEDO, Antônio Junqueira de (Coord.). São Paulo: Saraiva, 2007. V. 20, p. 196. 35 TARTUCE, Flávio; SIMÃO, José Fernando. Direito Civil. V. 6: direito das sucessões. 5. Ed. rev. e atual. São Paulo: Método, 2012, p. 101.

36 VELOSO, Zeno. Novo Código Civil Comentado. Coord. Ricardo Fiúza. São Paulo: Saraiva, 2006, p. 1.521.

37 PEREIRA, Caio Mário da Silva. Instituições de Direito Civil. V. VI, §436, p. 68. NADER, Paulo. Curso de Direito Civil. V. 6: direito das sucessões. Rio de Janeiro: Forense, 2007, p. 158-166.

38 TARTUCE, Flávio; SIMÃO, José Fernando. Direito Civil. V. 6: direito das sucessões. 5. Ed. rev. e atual. São Paulo: Método, 2012, p. 101. 
Para todos os efeitos, há de se ter em mente que a contagem do prazo prescricional inicia-se com a abertura da sucessão, que é o fato gerador do direito pleiteado.

Entende-se que o prazo será de 10 ou 20 anos a depender da data da abertura da sucessão.

Isso porque a regra para o CC/16 era de 20 anos e, por imposição do art. 2.028 do atual CC $^{39}$, se em 10 de janeiro de 2003 já havia se passado mais da metade do prazo prescricional previsto, permanecerá vigente a regra prescricional do código revogado.

Exemplificando, se a abertura da sucessão se deu em janeiro de 1992, haviam transcorrido onze anos quando da entrada em vigor do novo CC. Portanto, mais da metade do prazo previsto pelo $\mathrm{CC} / 16$, que era de 20 anos. Nesse caso, a lei do CC/16 será aplicada ao caso concreto, contado-se mais nove anos a partir de 11 de janeiro de 2003.

Se a abertura da sucessão se deu em janeiro de 1996, havia transcorrido apenas sete anos quando da entrada em vigor do novo CC. Ou seja, menos da metade do prazo previsto pelo antigo código. Nesse caso, o pra- zo deverá ser de 10 anos, seguindo a regra do CC/02, contando-se 10 anos a partir de 11 de janeiro de $2003^{40}$.

\section{CONSIDERAÇÕES FINAIS}

Constatou-se, após esta breve pesquisa, que o filho socioafetivo está equiparado pela $\mathrm{CF}$ aos demais filhos do autor da herança, bem como que a herança é um direito assegurado constitucionalmente.

A eficácia desse direito, para o filho socioafetivo ainda não declarado judicialmente, pode ser alcançada pela ação de investigação de filiação, cumulada com ação de petição de herança.

Quanto ao filho que pretende provar o vínculo biológico, a ação de investigação de filiação é plenamente viável, inclusive em razão do direito ao conhecimento de sua origem. Entretanto, fica obstada a alteração da filiação registral caso o investigante possua paternidade socioafetiva estabelecida.

Por corolário, o filho também não poderá buscar a herança do pai biológico. Nesse caso não haverá pos-

39 Art. 2.028, CC: Serão os da lei anterior os prazos, quando reduzidos por este Código, e se, na data de sua entrada em vigor, já houver transcorrido mais da metade do tempo estabelecido na lei revogada.

40 Código Civil Comentado: doutrina e jurisprudência. Coordenador César Peluso. $6^{\mathrm{a}}$ Ed. rev. e atual. Barueri, SP: Manole, 2012, p. 2.364. 
sibilidade de cumulação com ação de petição de herança.

Verificou-se, ainda, que a ação de investigação de filiação, por ser ação de estado, é imprescritível; ao passo que a ação de petição de herança, ação real de cunho pecuniário, sofre os efeitos da prescrição.

\section{REFERÊNCIAS}

ALMADA, Ney de Mello. Direito das Sucessões. Editora Brasiliense.

BOEIRA, José Bernardo Ramos. Investigação de Paternidade. Posse do Estado de Filho. Paternidade socioafetiva. Porto Algre: Livraria do Advogado, 1999.

CAHALI, Francisco José. HIRONAKA, Giselda Maria Fernandes Novaes. Direito das Sucessões. 4. ed. São Paulo: Revista dos Tribunais, 2012.

DIAS, Maria Berenice. Manual de Direito das famílias. Porto Alegre: Livraria do Advogado, 2 ed., 2005.

FACHIN, Luiz Edson. Da paternidade - relação biológica e afetiva. Belo Horizonte: Del Rey Editora, 1996. HIRONAKA, Giselda Maria Fernandes Novaes. Comentários ao Código Civil. 2. ed. AZEVEDO, Antônio Junqueira de (Coord.). São Paulo: Saraiva, 2007. V. 20.

LÔBO, Paulo. Direito Civil - Famílias. São Paulo: Saraiva. 2012.

NADER, Paulo. Curso de Direito Civil. V. 6: direito das sucessões. Rio de Janeiro: Forense, 2007.
PEREIRA, Rodrigo da Cunha. Código Civil da Família Anotado. Porto Alegre: Síntese, 2. ed., 2003. . (coordenador). Afeto, ética, família. Belo Horizonte: Del Rey, 2004.

PEREIRA, Sérgio Gischkow. Direito de Família. Aspectos do Casamento, sua eficácia, separação, divórcio, parentesco, filiação, regime de bens, alimentos, bem de família, união estável, tutela e curatela. Porto Alegre: Livraria do Advogado, 2007.

GOMES, Orlando. Sucessões. $12^{\mathrm{a}}$ ed. rev. atual. e aumentada de acordo com o Código Civil de 2002, por Mario Roberto Carvalho de Faria. Rio de Janeiro: Forense, 2004.

RIZZARDO, Arnaldo. Direito das Sucessões: Lei n. 10.406, de 10.01.2002. Rio de Janeiro: Forense, 2008.

VELOSO, Zeno. Novo Código Civil Comentado. Coord. Ricardo Fiúza. São Paulo: Saraiva, 2006.

VENOSA, Sílvio de Salvo. Direito Civil: direito das sucessões. $6^{\mathrm{a}}$ edição. São Paulo: Atlas, 2006. 